
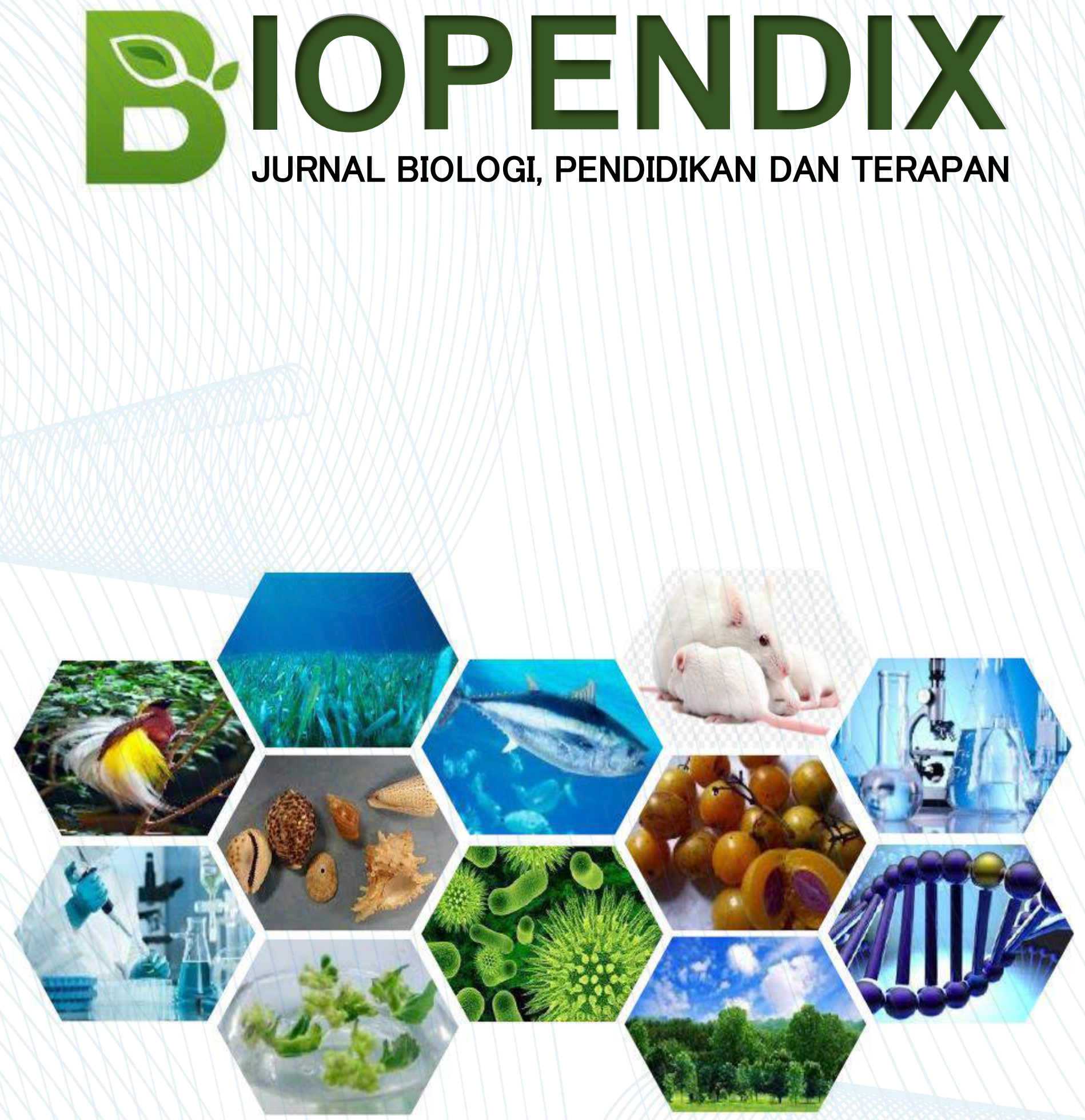

PUBLISHER BY:

BIOLOGY EDUCATION, UNPATTI AMBON - MALUKU 


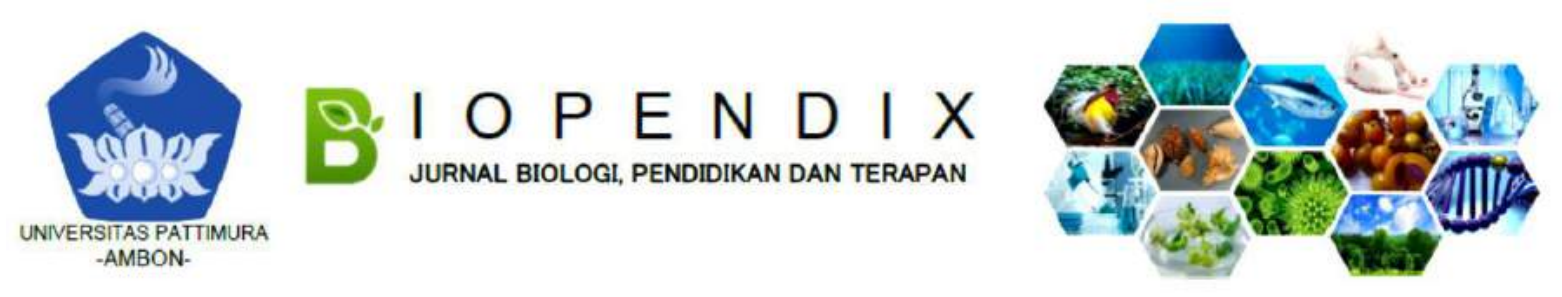

\title{
KEANEKARAGAMAN DAN POLA DISTRIBUSI \\ JENIS KEPITING BAKAU (Scylla Sp) PADA ZONA INTERTIDAL PANTAI DUSUN WAEL KABUPATEN SERAM BAGIAN BARAT
}

\author{
Wa Mega Wally ${ }^{1}$, M. Nur Matdoan², Ine Arini ${ }^{\star 2}$ \\ ${ }^{1}$ Alumni Program Studi Pendidikan Biologi; ${ }^{2}$ Program Studi Pendidikan Biologi \\ Corresponding author: Ine Arini; e-mail: iairini.unpatti@gmail.com
}

\begin{abstract}
Background: Mangrove forests are coastal ecosystems that usually grow along beaches or river mouths and are strongly influenced by tides. Mangrove crab (Scylla sp) is one of the important fisheries commodities in Indonesia. Mangrove crabs are very prospective as foodstuffs because they have an important nutritional value for the body, with $47.5 \%$ protein content and $11.20 \%$ fat. The intertidal zone of Wael hamlet is a coastal area located between the highest tides and lowest low tides. This area is a transition from ocean conditions to land conditions.

Method: This research uses descriptive research type, which is to express information descriptively about diversity and species distribution patterns.

Results: This study shows that mangrove crabs found in the mangrove forest area were 2 species, namely 7 species of Scylla sp and 5 species of Scylla oceanica.

Conclusion: This study shows that the diversity level of crabs is low while the distribution pattern of mangrove crabs is said to be clustered.
\end{abstract}

Keywords: Mangrove Forest, Intertidal Zone, Mangrove Crab

\begin{abstract}
Abstrak
Latar Belakang: Hutan mangrove merupakan ekosistem pesisir yang biasanya tumbuh di sepanjang pantai atau muara sungai dan sangat dipengaruhi oleh pasang surut air laut. Kepiting bakau (Scylla $s p$ ) merupakan salah satu komoditas perikanan penting di Indonesia. Kepiting bakau sangat prospektif dijadikan sebagai bahan pangan karena memiliki nilai nutrisi yang penting bagi tubuh, dengan kandungan nutrisi $47,5 \%$ protein dan $11,20 \%$ lemak. Zona intertidal pantai Dusun Wael merupakan daerah pantai yang terletak di antara pasang tertinggi dan surut terendah. Daerah ini merupakan daerah peralihan dari kondisi lautan ke kondisi daratan.

Metode: Penelitian ini menggunakan tipe penelitian deskriptif, yaitu untuk mengungkapkan informasi secara deskriptif tentang keanekaragaman dan pola distribusi jenis.

Hasil: Penelitian ini menunjukkan bahwa kepiting bakau yang ditemukan pada lokasi penelitian kawasan hutan mangrove terdapat 2 spesies, yaitu spesies Scylla sp sebanyak 7 ekor dan spesies scylla oceanica sebanyak 5 ekor.

Kesimpulan: Penelitian ini menunjukkan bahwa tingkat keanekaragaman dari kepiting rendah sedangkan pola distribusi dari jenis kepiting bakau dikatakan mengelompok.
\end{abstract}

Kata Kunci: Hutan Mangrove, Zona Intertidal, Kepiting Bakau 


\section{PENDAHULUAN}

Hutan mangrove merupakan ekosistem pesisir yang biasanya tumbuh di sepanjang pantai atau muara sungai dan sangat dipengaruhi oleh pasang surut air laut. Kepiting bakau (Scylla sp) merupakan salah satu komoditas perikanan penting di Indonesia (Kementerian Kelautan dan Perikanan, 2009). Kepiting bakau menjadi salah satu spesies kunci pada ekosistem pesisir karena, pada setiap aktivitas kepiting mempunyai pengaruh utama pada berbagai proses di dalam ekosistem. Peran kepiting bakau di dalam ekosistem diantaranya membantu daur karbon, menyediakan makanan alami pada jenis biota perairan, mengkonversi nutrien, meningkatkan distribusi oksigen di dalam tanah, serta mempertinggi mineralisasi. Tingkat kepadatan populasi kepiting bakau di kawasan hutan mangrove sangat bergantung pada kerapatan hutan mangrove (Chairunnisa, 2004).

Zona intertidal pantai Dusun Wael merupakan daerah pantai yang terletak di antara pasang tertinggi dan surut terendah. Daerah ini merupakan daerah peralihan dari kondisi lautan ke kondisi daratan walaupun luas daerah ini sangat terbatas, tetapi disini terdapat variasi faktor lingkungan yang sangat besar jika dibandingkan dengan daerah bahari lainnya (Sunarto, 2015). Pantai Dusun Wael merupakan pantai yang terdapat pada perairan di kecamatan Seram Barat, khususnya di kabupaten Seram Bagian Barat. Karakteristik wilayah ini umumnya datar dan berpasir serta memiliki substrat berpasir dan berpasir berbatu. Pantai Dusun Wael merupakan zona intertidal yang memperlihatkan berbagai jenis sumberdaya yang dapat dimanfaatkan secara terus menerus dengan adanya berbagai jenis organisme laut seperti kepiting bakau dan jenis yang lainnya (Arief, 2007). Tujuan dari penelitian ini adalah untuk mengetahui keanekaragaman dan pola distribusi kepiting bakau (Scylla $s p$ ) yang terdapat pada zona intertidal di pantai Dusun Wael.

\section{METODE}

Penelitian ini menggunakan tipe penelitian deskriptif, yaitu untuk mengungkapkan informasi secara deskriptif tentang keanekaragaman dan pola distribusi jenis kepiting bakau di Pantai Dusun Wael. Pelaksanaan penelitian ini dimulai dari tanggal 14 November sampai dengan 21 November 2017. Subjek dalam penelitian ini adalah semua kepiting bakau (Scylla $s p$ ) yang ada di perairan pantai Dusun Wael, Kecamatan Seram Barat, Kabupaten Seram Bagian Barat.

Alat dan bahan yang digunakan pada penelitian meliputi bubu dasar, tali arafia, tali nilon, kamera digital, alat tulis, cool box, buku identifikasi, dan kepiting bakau. Tahapan penelitian ini dilakukan mulai dari menyiapkan alat dan bahan. Tahapan penelitian dilakukan mulai dari tahap persiapan dan tahap pelaksanaan dalam penelitian.

\section{HASIL DAN PEMBAHASAN}

Hasil perhitungan indeks keanekaragaman, kemerataan, dan kekayaan pada kepiting bakau dapat dilihat pada tabel 1.

\section{Tabel 1. Hasil Perhitungan Indeks Keanekaragaman, Kemerataan, Dan Kekayaan Pada Kepiting Bakau}

\begin{tabular}{llccc}
\hline No. & Nama Spesies & H' & E & R \\
\hline 1. & Scylla $s p$ & 0,315 & 0,99 & 0,58 \\
2. & Scylla oceanica & 0,365 & 0,99 & 0,58 \\
& Total & $\mathbf{0 , 6 8}$ & $\mathbf{1 , 9 8}$ & $\mathbf{1 , 1 6}$ \\
\hline
\end{tabular}

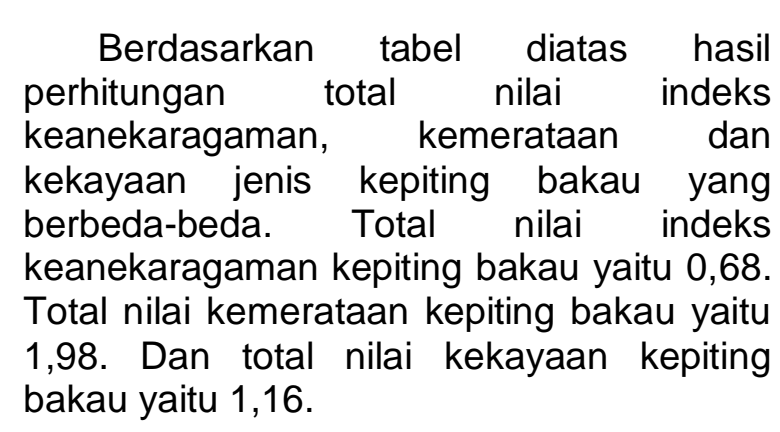


Tabel 2. Nilai Indeks Pola Distribusi pada Kepiting Bakau.

\begin{tabular}{clcl}
\hline No & $\begin{array}{c}\text { Spesie } \\
\text { s }\end{array}$ & $\begin{array}{c}\text { Indeks Pola } \\
\text { Distribusi }\end{array}$ & Keterangan \\
\hline 1 & Scylla $s p$ & 1,310 & $\begin{array}{l}\text { Distribusi } \\
\text { Mengelompok }\end{array}$ \\
2 & $\begin{array}{l}\text { Scylla } \\
\text { oceanica }\end{array}$ & 1,000 & Distribusi Acak \\
\hline
\end{tabular}

Dari tabel diatas menunjukkan bahwa nilai indeks pola distribusi kepiting bakau jenis Scylla sp mengelompok karena ID > 1 yaitu 1,310. Dan nilai indeks pola distribusi kepiting bakau jenis Scylla oceanica acak karena ID = 1 yaitu 1,000 .

\section{Keanekaragaman Jenis Kepiting Bakau Di Perairan Pantai Dusun Wael Kecamatan Seram Barat Kabupaten Seram Bagian Barat}

Kepiting bakau merupakan kepiting niaga yang mempunyai potensi untuk dikembangkan karena, rasa dagingnya yang enak dan kandungan protein yang begitu tinggi. Permintaan masyarakat terhadap kepiting ini semakin meningkat baik di dalam negeri maupun di luar negeri. Intensitas penangkapan kepiting bakau untuk mencukupi permintaan pasar yang semakin tinggi melatarbelakangi usaha budidaya kepiting bakau (Maharani, 2004).

Kepiting bakau sebagai sumber makanan dan pendapatan di Kosrae, Negara Bagian Micronesia, juga mengalami deplesi kelimpahan dan ukuran, akibat tekanan penangkapan yang dipengaruhi oleh distribusi penduduk dan lokasi usaha perikanan komersial. Penurunan populasi kepiting bakau di alam diduga disebabkan oleh degradasi ekosistem mangrove dan kelebihan tangkap (over exploitation) (Siahainenia, 2008).

Berdasarkan hasil yang diperoleh pada lokasi penelitian, terdapat 2 jenis kepiting bakau yang ditemukan yaitu, Scylla sp dan Scylla oceanica yang tergolong dalam famili Portunidae. Dari 2 jenis tersebut yang lebih mendominasi pada lokasi penelitian adalah Scylla sp dengan jumlah 7 ekor.

Tingginya tingkat keanekaragaman kepiting bakau disebabkan karena perairan pantai di Dusun Wael Kecamatan Seram Barat Kabupaten Seram Bagian Barat merupakan daerah berpasir serta memiliki substrat berpasir dan berpasir berbatu. Hal ini akan mendukung suatu spesies lain untuk saling beradaptasi membentuk suatu komunitas

Menurut Katili (2011), suatu komunitas dikatakan mempunyai keanekaragaman jenis tinggi, jika komunitas itu disusun oleh banyak spesies dengan kelimpahan spesies yang sama atau hampir sama. Sebaliknya jika komunitas itu disusun oleh sangat sedikit spesies dan hanya sedikit saja spesies yang dominan maka keanekaragaman jenisnya rendah.

\section{Kemerataan Jenis Kepiting Bakau Di Perairan Pantai Dusun Wael Kecamatan Seram Barat Kabupaten Seram Bagian Barat}

Kepiting bakau merupakan fauna yang habitat dan penyebarannya terdapat di air tawar, air payau, dan air laut. Jenis-jenisnya sangat beragam dan dapat hidup di berbagai kolom di setiap perairan. Sebagian besar kepiting yang kita kenal banyak hidup di perairan payau terutama di dalam ekosistem mangrove. Beberapa jenis yang hidup dalam ekosistem ini adalah Hermit Crab, Uca sp, Mud Lobster dan kepiting bakau. Sebagian besar kepiting merupakan fauna yang aktif mencari makan di malam hari nocturnal (Rusmadi, 2014).

Kemerataan jenis kepiting bakau pada lokasi penelitian memiliki nilai kemerataan dengan total nilai 1,98. Menurut Katili (2011), mengatakan bahwa apabila nilai kemerataan suatu komunitas berada pada rentang nilai 1,3-3,3 mengindikasi bahwa kemerataan suatu komunitas dikatakan rendah.

Dari hasil penelitian menunjukkan bahwa jenis kepiting bakau yang ditemukan masih berada dalam keadaan optimal bagi penyebaran kepiting bakau, ditambah lagi keadaan substrat yang berupa berpasir dan berpasir berbatu sehingga menyebabkan penyebaran komunitas kepiting bakau dikatakan rendah (Katili, 2011).

\section{Kekayaan Jenis Kepiting Bakau Di Perairan Pantai Dusun Wael Kecamatan Seram Barat Kabupaten Seram Bagian Barat}

Kekayaan spesies menunjukkan jumlah spesies dalam suatu komunitas. Nilai kekayaan kepiting bakau pada lokasi 
penelitian memiliki nilai kekayaan total yaitu 1,16. Dengan demikian nilai kekayaan jenis kepiting bakau pada lokasi penelitian dikategorikan rendah disebabkan karena, jumlah jenis kepiting bakau yang ditemukan di lokasi penelitian pada masing-masing spesies belum terlalu banyak.

Selain itu, tinggi rendahnya nilai kekayaan pada perairan pantai Dusun Wael juga dipengaruhi oleh perluasan kemampuan suatu organisme untuk hidup dan berkembangbiak pada daerah tersebut. Nilai kekayaan yang tinggi diduga juga berkaitan dengan tipe substrat yang sesuai sebagai habibat kepiting bakau dan adanya strategi adaptasi dan interaksi biologis antara populasi yang terdapat pada komunitas perairan tersebut.

\section{Pola Distribusi}

Nilai indeks distribusi hasil penelitian dapat dikategorikan distribusi mengelompok dan acak. Kepiting bakau untuk jenis Scylla $s p$ dan Scylla oceanica, indeks distribusi genusnya mengelompok dan acak disebabkan hewan ini memilih hidup pada habitat yang paling sesuai di dasar perairan dan hutan mangrove (Hubatsch, 2015).

\section{SIMPULAN}

Kesimpulan yang dapat diambil dari penelitian ini adalah indeks keanekaragaman kepiting bakau pada lokasi penelitian menunjukkan tingkat keanekaragaman rendah. nilai kemerataan kepiting bakau yang terdapat pada lokasi penelitian menyebar secara rendah. Nilai kekayaan kepiting bakau yang terdapat pada lokasi penelitian berkriteria rendah. Dan pola distribusi kepiting bakau jenis Scylla sp dikatakan mengelompok, karena indeks distribusi lebih besar dari 1 dan pola distribusi kepiting bakau jenis Scylla oceanica dikatakan acak, karena indeks distribusi sama dengan 1.

\section{DAFTAR PUSTAKA}

Arief, 2007. Hutan Mangrove, Fungsi dan Manfaatnya. Yogyakarta.

Chairunnisa. 2004. Kelimpahan Kepiting Bakau (Scylla Sp). Di Kawasan Hutan Mangrove KPH Batu Ampar, Kabupaten Pontianak, Kalimantan Barat. Skripsi. Fakultas Perikanan Dan IImu Kelautan, Institute Pertanian Bogor. Bogor.

Hubatsch, H.A., Lee S.Y., Meynecke, J.O., Diele, K., Nordhaus, I., \& Wolff, M. 2015. Life-History, Movement, and Habitat Use of Scylla Serrata (Decapoda-Portunidae). Current Knowledge and Future Challenges. Journal of Hydrobiologia (2016) 763: 5 $-21$.

Katili, 2011. Keanekaragaman Hayati Laut. Aspek Berkelanjutan Indonesia. PT Gramedia Pustaka Utama. Jakarta.

Kementerian Kelautan dan Perikanan, 2009. Kelautan dan Perikanan Dalam Angka. Marine and Fisheries in Figure. www.googlechrome.com., diakses 7 Agustus 2019.

Maharani, R.I. 2004. Sentivitas Berbagai Stadia Kepiting Bakau (Scylla Paramamosain Estampador) Terhadap White Spot Syndrome Virus. Jurnal Penelitian Pertanian. Sumatera Utara.

Rusmadi. 2014. Studi Biologi Kepiting di Perairan Teluk Dalam Desa Malang Rapat Kabupaten Bintan, Provinsi Kepulauan Riau. Skripsi. Universitas Maritim Raja Ali Haji. Tanjung Pinang.

Siahainenia. 2008. Biologi Kepiting Bakau (Scylla sp) di Ekosistem Mangrove Kabupaten Subang Jawa Barat. Disertasi. Program Pascasarjana IPB. Bogor.

Sunarto. 2015. Hubungan Antara Keberadaan Kepiting Bakau (Scylla sp) Kondisi Mangrove dan Substrat di Kawasan Tambak Silvofishery, Eretan Indramayu. Tesis. Program Pascasarjana IPB. Bogor. 